\title{
MEDIA PEMBELAJARAN MATEMATIKA BERBASIS KOMPUTER PADA MATERI FUNGSI
}

\author{
Alzuwandi, Jalinus \\ Pendidikan Matematika, Universitas Riau \\ Email : alzuwandi@gmail.com
}

\begin{abstract}
Computer technology can be utilized to create interactive learning media in the form of multimedia. Along with the development of technology need to make a computer-based learning media to help learners and teachers in learning, especially mathematics. In school, teachers use the material only from cardboard media and affixed to the blackboard, and even then not the students who hold it, so far the teacher taught mathematics only using textbooks and LKS, even though the teacher already has a computer or laptop and in the school already has facilities to support the use of media based computer that is one of them is LCD projector. One way that can be done is to create interactive learning media and interesting for learners. This study aims to develop a computer-based learning media that is valid to help students understand about functions. The research steps to be done is to analyze the syllabus, RPP and textbooks, collect the required images or animations, create paper based media designs, create media on powerpoints, create frontpage, and ask to validate by experts and practitioners. The program used for the design of computer-based products is a frontpage program, microsoft power point. Learning media validated by three experts or validators and then be revised according to validator's advice. Learning media is packaged in the form of compact disk (CD) and user manual.
\end{abstract}

Keywords : Learning media mathematics, Computers, Functions

\section{PENDAHULUAN}

Semakin pesat perkembangan Teknologi Informasi dan Komunikasi (TIK) saat ini telah mengubah cara pandang, serta kemampuan berpikir secara praktis dan efisien pada masyarakat. Perkembangan teknologi komputer memungkinkan penayangan informasi grafis, teks, suara dan gambar sehingga memungkinkan dibuatnya media audiovisual yang interaktif. Ketidakjelasan bahan yang disampaikan dalam kegiatan belajar mengajar, dapat dibantu dengan menghadirkan media (Bahri, 2010). Dengan kata lain, pemilihan dan penggunaan media pembelajaran secara tepat akan sangat berguna dalam proses pembelajaran, sehingga peserta didik dapat lebih mudah memahami materi dengan bantuan media.

Dari observasi di beberapa SMP yang ada di kota pekanbaru, diperoleh fakta bahwa masih kurangnya pengembangan media tutorial interaktif. Guru jarang menggunakan media pembelajaran matematika. Media yang dipergunakan guru hanya sebatas karton yang ditempelkan di papan tulis, interaksi peserta didik dengan media tersebut juga sangat kurang. Hasil pengamatan dan wawancara dengan beberapa orang guru matematika SMP tersebut diperoleh bahwa guru juga tidak membuat media berbasis komputer untuk mengajar materi matematika, selama ini guru mengajar matematika di SMP hanya menggunakan buku ajar dan LKS, dan sekolah sudah memiliki fasilitas untuk menunjang penggunaan media berbasis komputer tersebut yaitu salah satunya adalah LCD proyektor.

Berdasarkan penjelasan di atas, peneliti memiliki keinginan untuk memberikan solusi dari kondisi tersebut. Dalam proses pembelajaran, agar pembelajaran lebih menarik dan peserta didik lebih termotivasi untuk belajar, maka perlu menggunakan TIK. Pengembangan media pembelajaran interaktif model tutorial berbasis komputer dapat membantu peserta didik dalam proses pembelajaran dan membantu guru dalam menyampaikan materi pembelajaran sehingga materi dapat tersampaikan dengan baik dan dipahami oleh peserta didik dengan memanfaatkan fasilitas yang sudah ada sebagai penunjang proses pembelajaran berbasis komputer.

Media pembelajaran yang menyajikan gambar grafis, teks dan suara akan membangkitkan motivasi peserta didik dalam mempelajari konsep relasi dan fungsi. Media yang dibuat menunjang pembelajaran berbasis komputer model tutorial interaktif, dengan materi relasi dan fungsi disajikan dalam Power Point dan ditampilkan dalam Microsoft 
Frontpage. Power Point merupakan aplikasi microsoft office yang digunakan untuk melakukan desain dan membangun perangkat presentasi, publikasi, atau aplikasi lainnya yang membutuhkan ketersediaan sarana interaksi dengan penggunaannya.

Kelebihan yang dimiliki, software microsoft office Power Point dapat membantu peserta didik dalam memahami konsep matematika. Pada bahan ajar berbasis komputer ini, setiap materi dibuat dalam slide dengan gambar-gambar dan animasi disertai keterangan yang sesuai. Microsoft frontpage adalah sebuah program untuk membuat, mendesain, mengedit halaman world wide web seperti menambahkan text, form, dan elemen lain di halaman web yang selanjutnya ditampilkan dalam bentuk browser. Microsoft frontpage dirancang sebagai tool agar mudah untuk menghasilkan halaman atau situs web, tanpa perlu pemrograman. Microsoft frontpage dalam penelitian ini masih bersifat offline yang bisa saja sewaktu-waktu diubah menjadi online. Media pembelajaran berbasis komputer model tutorial interaktif ini dapat membantu dan memotivasi peserta didik belajar. Penelitian ini perlu dilakukan karena saat ini guru dituntut untuk bisa menggunakan teknologi dalam proses pembelajaran dan untuk meningkatkan kompetensi profesional guru dan juga tuntutan perkembangan teknologi, informasi dan komunikasi saat ini. Penelitian pengembangan media pembelajaran berbasis komputer model tutorial interaktif ini pada pokok materi relasi dan fungsi valid dan memenuhi syarat praktikalitas untuk digunakan peserta didik kelas VIII.

Media komputer merupakan media yang menarik, atraktif, dan interaktif. Pembelajaran komputer sebagai media pembelajaran sangat tepat untuk belajar mandiri dalam pendidikan jarak jauh. Pembelajar dapat belajar di lingkungan keluarga, karena komputer pada masa sekarang ini sudah menjadi bagian kebutuhan dari suatu keluarga. Keluarga dapat mendampingi dan membimbing pembelajar secara mandiri menggunakan computer.

\section{METODE}

Rancangan penelitian pengembangan ini mengadaptasi model pengembangan $R \& D$ oleh Borg and Gall yang dimodifikasi oleh Sugiyono (2011). Adapun langkah-langkah pengembangannya adalah: (1) potensi dan masalah; (2) pengumpulan data; (3) desain produk; (4) validasi desain; (5) perbaikan desain; (6) uji coba produk; (7) revisi produk (8) uji coba pemakaian; (9) revisi produk; dan (10) pembuatan produk massal. Pada penelitian ini hanya sampai pada tahap (9), karena tahap (10) merupakan tahap penggunaan media pembelajaran yang telah dikembangkan pada skala yang lebih luas, misalnya di sekolah lain dan di daerah lain.

\section{HASIL DAN PEMBAHASAN}

Pengembangan media pembelajaran berbasis komputer model tutorial interaktif untuk pokok materi relasi dan fungsi kelas VIII melalui beberapa tahap. Tahap-tahap tersebut adalah sebagai berikut.

1. Desain Awal Produk

Media pembelajaran berbasis komputer model tutorial interaktif untuk pokok materi relasi dan fungsi kelas VIII dibuat menggunakan program microsoft powerpoint dan bersifat interaktif. Setiap materi dibuat dengan animasi dan gambar-gambar dengan disertai keterangan yang sesuai. Dengan media pembelajaran berbasis komputer model tutorial interaktif ini dapat membantu dan memudahkan peserta didik untuk belajar mandiri.

Sebelum mendesain

media pembelajaaran berbasis komputer model tutorial interaktif untuk pokok materi relasi dan fungsi kelas VIII, peneliti mengumpulkan bahan yang diperlukan untuk membuat media berupa materi ajar dan soal-soal latihan untuk materi pokok relasi dan fungsi yang diperoleh melalui bukubuku pelajaran matematika SMP kelas VIII kurikulum 20113 maupun internet. Peneliti juga mengumpulkan bahan berupa gambar-gambar yang dibutuhkan untuk membuat ilustrasi, background, animasi, serta tombol-tombol navigasi yang digunakan pada media. Materi relasi dan fungsi pada media pembelajaran disusun mengacu pada kurikulum 2013. Kompetensi Dasar (KD) yang yang digunakan pada silabus mata pelajaran matematika kurikulum 2013 di penelitian ini yaitu KD 3.3 dan 3.4.

Tahap desain produk dilakukan dengan membuat rancangan awal program menggunakan paper based design. Paper based design merupakan rancangan awal media pembelajaran yang dibuat pada kertas. Setelah paper based design selesai dibuat, desain 
produk yang telah dirancang kemudian dibuat dalam komputer menggunakan program Microsoft Office Power Point. Peneliti juga menggunakan Adobe Photoshop CS 4 dalam membuat gambar yang digunakan pada media pembelajaran ini. Setelah media pembelajaran selesai dibuat menggunakan program Microsoft Office Power Point kemudian dikemas dalam tampilan web yang dibuat menggunakan Microsoft Front Page.

2. Validasi Produk

Pada tahap ini dilakukan validasi terhadap media pembelajaran berbasis komputer model tutorial interaktif pada materi relasi dan fungsi kelas VIII. Validasi yang peneliti lakukan pada penelitian ini adalah validasi konstruksi yaitu dengan menggunakan pendapat para ahli (judgement expert). Media pembelajaran ini dinilai oleh 3 orang validator yaitu 2 orang dosen dan satu orang guru matematika SMP kelas VIII.

Validasi untuk media pembelajaran berbasis komputer model tutorial interaktif pada materi pokok relasi dan fungsi dinilai dari 4 aspek yaitu aspek pembelajaran, aspek kurikulum, aspek program dan aspek kosmetik. Pelaksanaan validasi ini dilakukan pada 23 September 2017 sampai 17 Oktober 2017 Proses validasi media pembelajaran dimulai dengan menemui validator. Kemudian peneliti memberikan media pembelajaran berbasis komputer model tutorial interaktif pada materi relasi dan fungsi kelas VIII dalam bentuk Compact Disk (CD) dan memberikan lembar validasi media pembelajaran. Validator melihat dan menilai media tersebut dan selanjutnya mengisi lembar validasi sesuai dengan penilaian validator terhadap media pembelajaran berbasis komputer model tutorial interaktif pada materi pokok relasi dan fungsi kelas VIII. Hasil validasi media pembelajaran berbasis komputer model tutorial interaktif pada materi pokok bilangan bulat kelas IV dari tiga orang validator dapat dilihat pada Tabel 1 berikut.

Tabel 1. Hasil Validasi Media Pembelajaran

\begin{tabular}{llccc}
\hline No & Validator & Jumlah & $\begin{array}{c}\text { Rata- } \\
\text { rata }\end{array}$ & Keterangan \\
\hline 1. & Validator 1 & 127 & 3.8 & Sangat Valid \\
2. & Validator 2 & 126 & 3.8 & Sangat Valid \\
3. & Validator 3 & 125 & 3.7 & Sangat Valid \\
\hline
\end{tabular}

Hasil validasi media pembelajaran berbasis komputer model tutorial interaktif pada materi pokok relasi dan fungsi kelas VIII dinilai telah sangat valid. Hasil validasi media pembelajaran dari validator 1 memperoleh nilai rata-rata sebesar 3.8 dengan keterangan sangat valid. Dari validator 2 diperoleh rata-rata 3.8 dengan keterangan sangat valid dan 3.7 dari validator 3 dengan keterangan sangat valid. Sehingga, dari 3 orang validator diperoleh nilai rata-rata keseluruhan yaitu 3.76 yang berarti masuk dalam kategori sangat valid. Hasil validasi tersebut dipaparkan pada penjelasan berikut.

a. Hasil Validasi Aspek Kurikulum

Hasil validasi media pembelajaran berbasis komputer model tutorial interaktif pada materi pokok relasi dan fungsi kelas VII untuk aspek kurikulum dinilai telah valid. Namun pada butir no 2, dua orang validator memberikan nilai 3 yaitu sesuai. Validator memberikan masukan untuk memperbaiki indikator kompetensi agar tercapai Kompetensi Dasar tentang keterampilan.

b. Hasil Validasi Aspek Pembelajaran

Hasil validasi untuk aspek pembelajaran sudah baik. Keseluruhan butir untuk aspek pembelajaran dinilai sudah valid. Namun untuk aspek pembelajaran butir no 8 yaitu materi pembelajaran dibuat sesuai dengan tujuan pembelajaran, dua orang validator memberi nilai 3 yaitu sesuai. Validator menyarankan untuk memperbaiki bahasa dalam tujuan pembelajaran.

\section{c. Hasil Validasi Aspek Program}

Hasil validasi media pembelajaran berbasis komputer model tutorial interaktif pada materi pokok relasi dan fungsi kelas VIII pada aspek program dinilai sudah baik. Seluruh butir pernyataan untuk aspek program dinilai telah valid oleh validator. Namun untuk butir nomor 21 yaitu kecepatan pergantian animasi sudah tepat, 2 orang validator memberikan nilai 3 yang artinya sesuai. Validator menyarankan agar kecepatan pergantian animasi jangan terlalu lama. Pada butir nomor 23 yaitu penggunaan link pada media berfungsi dengan benar, salah seorang memberikan nilai 2 yaitu tidak sesuai. Hal ini dikarenakan validator masih menemukan beberapa link yang tidak berjalan sebagaimana mestinya. Salah satu validator juga menyarankan agar kompetensi inti di buat pada halaman yang sama agar pengguna lebih mudah mengetahuinya dan tidak berpindah ke halaman lain. 


\section{d. Hasil Validasi Aspek Kosmetik}

Hasil validasi media pembelajaran berbasis komputer model tutorial interaktif pada materi pokok relasi dan fungsi kelas VIII pada aspek program dinilai sudah baik. Seluruh butir pernyataan untuk aspek kosmetik dinilai sudah baik oleh validator. Namun untuk butir nomor 29 yaitu penggunaan warna dan gambar pada media mendukung pembelajaran peserta didik, salah seorang validator memberikan nilai 3 yaitu sesuai. Validator menyarankan warna background pada materi 1 sesuai dengan background tujuan pembelajaran. Kemudian pada butir nomor 33 yaitu media bebas dari kesalahan pengetikan, 1 orang validator memberikan nilai 2 yaitu tidak setuju. Hal ini dikarenakan masih banyak kesalahan tulisan yang ditemukan validator dalam media pembelajaran.

\section{Revisi Desain}

Berdasarkan penilaian pada angket validasi serta komentar dan saran dari validator terhadap media pembelajaran berbasis komputer model tutorial interaktif pada materi pokok relasi dan fungsi kelas VIII. Peneliti merevisi media pembelajaran berbasis komputer model tutorial interaktif pada materi pokok relasi dan fungsi kelas VIII dari empat aspek tersebut. Revisi yang dilakukan oleh peneliti pada aspek kurikulum dapat dilihat pada Tabel 2 berikut.

Tabel 2. Revisi Media Pembelajaran Pada Aspek Kurikulum

\begin{tabular}{ccll}
\hline No & $\begin{array}{c}\text { Komponen } \\
\text { Awal }\end{array}$ & $\begin{array}{l}\text { Penilaian dan } \\
\text { Saran } \\
\text { Validator }\end{array}$ & $\begin{array}{l}\text { Hasil } \\
\text { Revisi }\end{array}$ \\
\hline 1. & Rumusan & Perlihatkan & Rumusan \\
& Indikator & indikator \\
& & indikator \\
& & dentang \\
& & deterampilan \\
& & mengerjaan \\
& & \\
& & soal \\
\hline
\end{tabular}

Komponen Awal

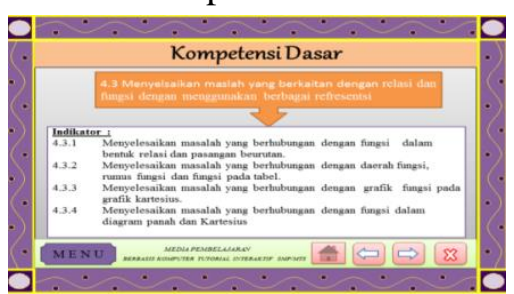

Setelah Revisi

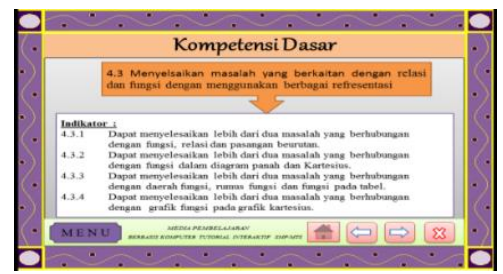

Gambar 1. Revisi Media Pembelajaran Pada Aspek Kurikulum

Revisi yang dilakukan oleh peneliti pada aspek pembelajaran dapat dilihat pada Tabel 3 berikut.

Tabel 3. Revisi Media Pembelajaran Pada Aspek Pembelajaran

\begin{tabular}{|c|c|c|c|}
\hline No & $\begin{array}{c}\text { Komponen } \\
\text { Awal }\end{array}$ & $\begin{array}{l}\text { Penilaian } \\
\text { dan Saran } \\
\text { Validator }\end{array}$ & Hasil Revisi \\
\hline 1. & $\begin{array}{l}\text { Tujuan } \\
\text { Pembelajaran }\end{array}$ & $\begin{array}{l}\text { Perbaiki } \\
\text { bahasa } \\
\text { dalam tujuan } \\
\text { pembelajaran }\end{array}$ & $\begin{array}{l}\text { Bahasa } \\
\text { tujuan } \\
\text { pembelajaran } \\
\text { diperbaiki }\end{array}$ \\
\hline 2 & $\begin{array}{l}\text { Kesimpulan } \\
\text { diakhir } \\
\text { materi terlalu } \\
\text { diperlihatkan }\end{array}$ & $\begin{array}{l}\text { Biarkan } \\
\text { peserta didik } \\
\text { berfikir dan } \\
\text { buat pilihan } \\
\text { agar peserta } \\
\text { didik bisa } \\
\text { memilih } \\
\text { yang di } \\
\text { anggap benar }\end{array}$ & $\begin{array}{l}\text { Kesimpulan } \\
\text { diperbaiki } \\
\text { dengan } \\
\text { membuat } \\
\text { pilihan pada } \\
\text { akhir } \\
\text { pembelajaran } \\
\text { untuk } \\
\text { membuat } \\
\text { peserta didik } \\
\text { berfikir. }\end{array}$ \\
\hline
\end{tabular}

Komponen Awal

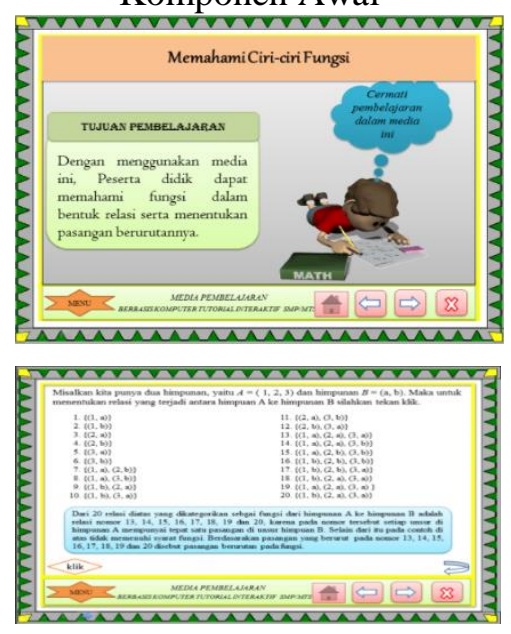



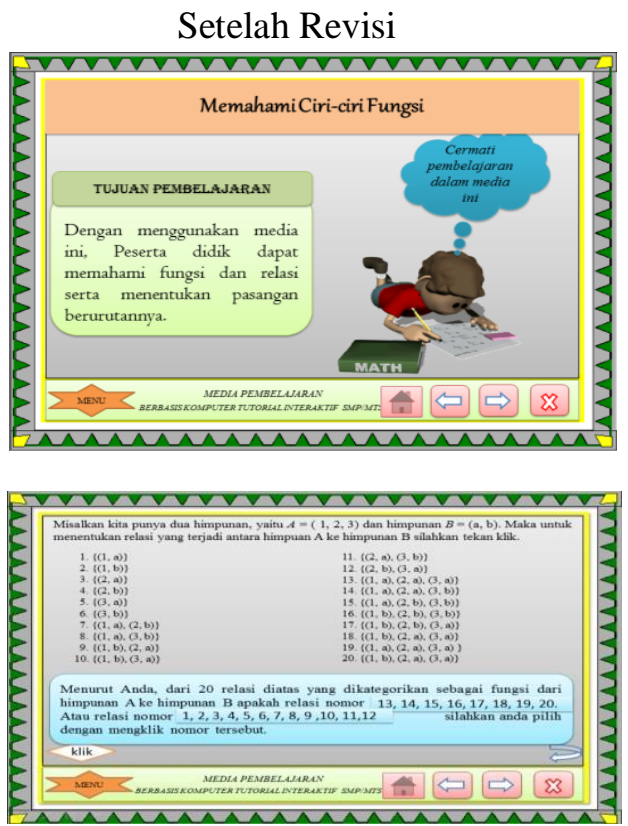

Gambar 2. Revisi Media Pembelajaran Pada Aspek Pembelajaran

Revisi yang dilakukan oleh peneliti pada aspek program dapat dilihat pada Tabel 4 berikut.

Tabel 4. Revisi Media Pembelajaran Pada Aspek Program

\begin{tabular}{|c|c|c|c|}
\hline No & $\begin{array}{c}\text { Komponen } \\
\text { Awal }\end{array}$ & $\begin{array}{c}\text { Penilaian } \\
\text { dan Saran } \\
\text { Validator }\end{array}$ & Hasil Revisi \\
\hline 1. & $\begin{array}{l}\text { Durasi } \\
\text { animasi } \\
\text { terlalu } \\
\text { lambat }\end{array}$ & $\begin{array}{l}\text { Percepat } \\
\text { durasi } \\
\text { munculnya } \\
\text { animasi }\end{array}$ & $\begin{array}{l}\text { Durasi } \\
\text { animasi dari } \\
2 \text { detik } \\
\text { setiap } \\
\text { animasi } \\
\text { diperbaiki } \\
\text { menjadi } \\
\text { 1detik setiap } \\
\text { animasi. }\end{array}$ \\
\hline 2 & $\begin{array}{l}\text { Link pada } \\
\text { media }\end{array}$ & $\begin{array}{l}\text { Terdapat } \\
\text { link yang } \\
\text { tidak } \\
\text { berjalan } \\
\text { sebagaimana } \\
\text { mestinya. }\end{array}$ & $\begin{array}{l}\text { Link tombol } \\
\text { exit pada } \\
\text { materi } 2 \\
\text { tidak } \\
\text { berjalan } \\
\text { sebagimana } \\
\text { mestinya. } \\
\text { Tombol exit } \\
\text { tersebut di } \\
\text { link kan ke } \\
\text { halaman } \\
\text { cover } \\
\text { materi. Link }\end{array}$ \\
\hline
\end{tabular}
telah
diperbaiki dan berjalan sebagaimana mestinya.

Revisi yang dilakukan oleh peneliti pada aspek kosmetik dapat dilihat pada Tabel 5 berikut.

Tabel 5. Revisi Media Pembelajaran Pada Aspek Kosmetik

\begin{tabular}{|c|c|c|c|}
\hline No & $\begin{array}{c}\text { Komponen } \\
\text { Awal }\end{array}$ & $\begin{array}{c}\text { Penilaian dan } \\
\text { Saran } \\
\text { Validator }\end{array}$ & Hasil Revisi \\
\hline 1. & $\begin{array}{l}\text { Background } \\
\text { pada materi } 1\end{array}$ & $\begin{array}{l}\text { Background } \\
\text { sesuaikan } \\
\text { dengan } \\
\text { background } \\
\text { tujuan } \\
\text { pembelajaran }\end{array}$ & $\begin{array}{l}\text { Background } \\
\text { pada materi } 1 \\
\text { diperbaiki }\end{array}$ \\
\hline 2 & $\begin{array}{l}\text { Terdapat } \\
\text { kesalahan } \\
\text { pengetikan }\end{array}$ & $\begin{array}{l}\text { Perbaiki } \\
\text { pengetikan } \\
\text { pada media } \\
\text { terutama pada } \\
\text { materi. }\end{array}$ & $\begin{array}{l}\text { Pengetikan } \\
\text { diperbaiki } \\
\text { pada media } \\
\text { dan materi }\end{array}$ \\
\hline
\end{tabular}

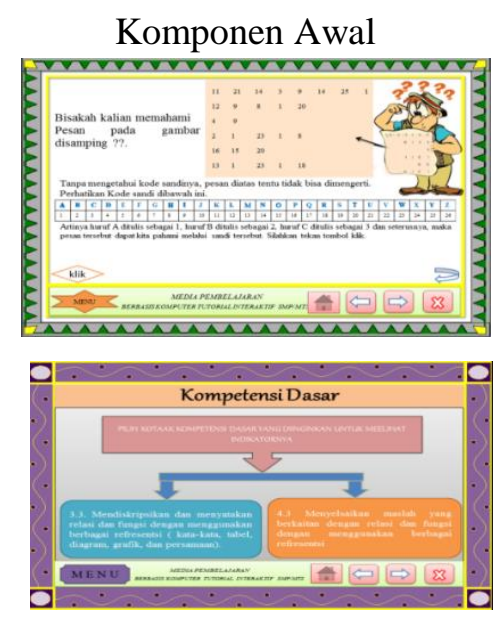

Setelah Revisi
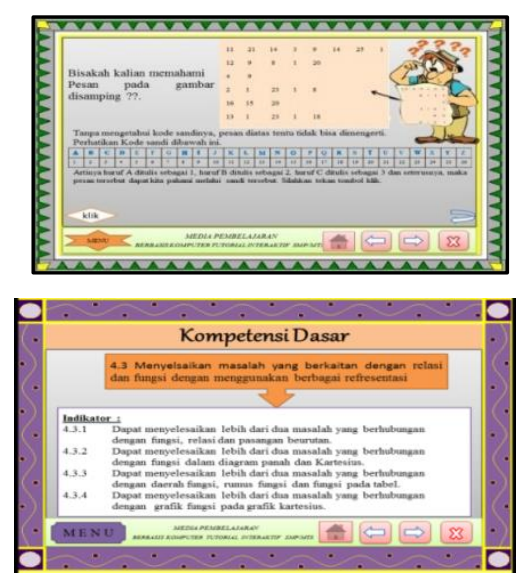

Gambar 3. Revisi Media Pembelajaran Pada Aspek Kosmetik 


\section{Uji Coba}

Uji coba media pembelajaran berbasis komputer model tutorial interaktif pada materi pokok relasi dan fungsi kelas VIII dilakukan sebanyak 2 kali yaitu sebagai berikut.

a. Uji Coba Kelompok Kecil

Pada tahap uji coba kelompok kecil, media pembelajaran berbasis komputer model tutorial interaktif pada materi pokok relasi dan fungsi kelas VIII yang telah direvisi diuji cobakan kepada peserta didik kelas VIII SMP IT Raudhatur Rahmah Pekanbaru dengan kemampuan akademis yang heterogen. Peserta didik dipilih berdasarkan nilai Ulangan Harian pada semester genap tahun ajaran 2017/2018. Dipilih 5 orang peserta didik yang terdiri atas 1 orang peserta didik dengan kemampuan tinggi, 2 orang peserta didik dengan kemampuan sedang dan 2 orang peserta didik dengan kemampuan rendah. Hal ini dimaksudkan agar peneliti dapat melihat apakah media pembelajaran ini dapat membuat peserta didik memahami materi bilangan bulat dengan baik. Tahap uji coba ini dilakukan pada hari senin, 6 November 2017.

Pada tanggal 6 Oktober 2017, peneliti meminta 5 orang peserta didik yang dipilih untuk menggunakan media pembelajaran berbasis komputer model tutorial interaktif pada materi pokok relasi dan fungsi kelas VIII. Pada uji coba ini, peserta didik menggunakan media pembelajaran untuk materi 1 sampai 4 . Sebelum menggunakan media pembelajaran, peneliti memberikan informasi terkait penggunaan media serta langkah-langkah uji coba. Peneliti menjelaskan bahwa setelah peserta didik menggunakan media pembelajaran ini untuk semua materi, peneliti akan memberikan lembaran tanggapan yang harus diisi dengan oleh peserta didik.

Pada awal proses uji coba, peneliti meminta peserta didik untuk membuka media pembelajaran. Peneliti meminta peserta didik untuk mengikuti langkah-langkah pada media pembelajaran. Kemudian peneliti mengarahkan peserta didik untuk membaca dan memahami petunjuk penggunaan. Selama peserta didik belajar menggunakan media pembelajaran, peneliti bertindak sebagai pendamping. Jika sewaktu-waktu peserta didik mengalami kesulitan atau membutuhkan bantuan maka peneliti akan memberikan bantuan ataupun arahan. Dalam proses uji coba, beberapa peserta didik ada yang bertanya. Ada yang bertanya mengenai penjelasan materi dan ada juga yang bertanya tentang penggunaan tombol yang terdapat pada media. Peneliti juga mengamati kegiatan pembelajaran dan melihat respon peserta didik selama menggunakan media pembelajaran. Peneliti melihat antusiasme yang tinggi dari peserta didik. Peneliti juga melihat bahwa peserta didik dapat memahami materi pembelajaran dengan baik. Hal ini terlihat pada saat peneliti bertanya mengenai materi pembelajaran, peserta didik dapat menjawab dengan benar.

Setelah peserta didik memahami materi, peserta didik masuk ke bagian soal-soal latihan. Pada saat mengerjakan soal-soal latihan, peserta didik terlihat sangat bersemangat. Peneliti juga melihat peserta didik dapat menjawab soal-soal latihan dengan baik dan mereka terlihat senang ketika berhasil menjawab soal dengan benar. Namun ada juga peserta didik yang menjawab salah. Peserta didik sudah mengerti materi pembelajaran hanya saja kurang teliti dalam membaca pilihan jawaban. Setelah peserta didik selesai mengerjakan soal-soal latihan, kemudian peneliti membagikan angket yang harus diisi oleh peserta didik. Ketika peserta didik selesai mengisi angket, peneliti kemudian melakukan diskusi untuk memperoleh informasi yang lebih dalam dan akurat terkait uji coba yang telah dilakukan.

Peneliti merangkum data hasil angket respon peserta didik pada uji coba kelompok kecil. Kemudian peneliti menganalisis hasil angket respon peserta didik pada uji coba kelompok kecil dengan menghitung persentase hasil respon peserta didik pada media pembelajaran berbasis komputer model tutorial interaktif pada materi pokok relasi dan fungsi kelas VIII dengan nilai rata2 hasil penilaian peserta didik sebesar 0,96 termasuk dalam kategori "sangat baik".

Berdasarkan hasil angket respon peserta didik dan wawancara singkat peneliti dengan peserta didik, diperoleh bahwa peserta didik merasa lebih senang belajar menggunakan media pembelajaran berbasis komputer model tutorial interaktif pada materi pokok relasi dan fungsi kelas VIII ini. Peserta didik mengatakan bahwa dengan menggunakan media pembelajaran berbasis computer ini menambah semangat dan motivasi dalam belajar. Peserta didik juga dapat mengoperasikan media 
pembelajaran dengan mudah walaupun baru pertama kali menggunakan media pembalajaran berbasis komputer. Hal ini dikarenakan media telah dilengkapi dengan petunjuk penggunaan yang jelas.

Dari hasil yang diperoleh, peneliti melakukan revisi terhadap media sesuai dengan penilaian dari uji coba kelompok kecil. Revisi yang dilakukan peneliti dapat dilihat pada Tabel 6.

Tabel 6. Revisi Media Pembelajaran Uji Coba Kelompok Kecil

\begin{tabular}{|c|c|c|c|}
\hline No & $\begin{array}{c}\text { Komponen } \\
\text { Awal }\end{array}$ & $\begin{array}{c}\text { Penilaian } \\
\text { dan Saran } \\
\text { Validator }\end{array}$ & Hasil Revisi \\
\hline 1. & $\begin{array}{l}\text { link pada } \\
\text { media }\end{array}$ & $\begin{array}{l}\text { Terdapat } \\
\text { link yang } \\
\text { tidak } \\
\text { berjalan } \\
\text { sebagaima } \\
\text { na } \\
\text { mestinya. }\end{array}$ & $\begin{array}{l}\text { Link } \\
\text { tombol exit } \\
\text { pada pilihan } \\
\text { materi } \\
\text { tidak } \\
\text { berjalan } \\
\text { sebagimana } \\
\text { mestinya. } \\
\text { Tombol exit } \\
\text { tersebut di } \\
\text { link kan ke } \\
\text { halaman } \\
\text { pilihan } \\
\text { cover } \\
\text { media } \\
\text { pembelajara } \\
\text { n. Link telah } \\
\text { diperbaiki } \\
\text { dan berjalan } \\
\text { sebagaiman } \\
\text { a mestinya. }\end{array}$ \\
\hline 2 & $\begin{array}{l}\text { Terdapat } \\
\text { kesalahan } \\
\text { pengetikan }\end{array}$ & $\begin{array}{l}\text { Perbaiki } \\
\text { pengetikan } \\
\text { pada } \\
\text { materi } \\
\text { pembelajar } \\
\text { an. }\end{array}$ & $\begin{array}{l}\text { Pengetikan } \\
\text { diperbaiki } \\
\text { pada materi } \\
3 \text { tentang } \\
\text { kalimat } \\
\text { contoh soal. }\end{array}$ \\
\hline
\end{tabular}

b. Uji Coba Kelompok Besar

Setelah media pembelajaran berbasis komputer model tutorial interaktif pada materi pokok relasi dan fungsi kelas VIII direvisi sesuai dengan hasil uji coba kelompok kecil, selanjutnya peneliti melakukan uji coba kelompok besar. Uji coba kelompok besar dilaksanakan pada kamis, 9 November 2017. Uji coba dilakukan di kelas VIII SMP IT Raudhatur Rahmah Pekanbaru dengan jumlah peserta didik sebanyak 16 orang yang telah mempelajari materi pokok relasi dan fungsi.
Peserta didik yang telah melakukan uji coba kelompok kecil tidak diikutsertakan pada uji coba kelompok besar.

Pada uji coba kelompok besar, peneliti mengujicobakan media pembelajaran dalam proses pembelajaran di kelas. Pada uji coba ini, peneliti bertindak sebagai guru yang melaksanakan pembelajaran. Pada pembelajaran yang dilakukan, peserta didik berusaha memahami sendiri materi pembelajaran dengan menggunakan media pembelajaran yang telah dibuat. Jika ada hal-hal yang tidak dimengerti, barulah kemudian guru yang akan menjelaskan kepada peserta didik. Di awal pembelajaran, peneliti mengkondisikan peserta didik agar siap mengikuti pembelajaran. Sebelum menggunakan media, peneliti terlebih dahulu memberikan informasi tentang media yang akan digunakan, tata cara penggunaannya serta menjelaskan langkah-langkah uji coba. Kemudian, peneliti mengarahkan peserta didik untuk membuka media pembelajaran yang berada pada komputer masing-masing. Peneliti meminta peserta didik untuk memahami petunjuk penggunaan media pembelajaran ini. Setelah peserta didik memahami petunjuk penggunaan media, peserta didik dipersilahkan untuk belajar dengan menggunakan media tersebut. Peneliti meminta peserta didik untuk mencatat dan mengerjakan soal-soal yang terdapat pada media pembelajaran di buku catatan masing-masing.

Ketika peserta didik menggunakan media pembelajaran, peneliti mengamati kegiatan pembelajaran dan respon peserta didik terhadap media pembelajaran yang digunakan. Peserta didik terlihat sangat antusias ketika belajar menggunakan media pembelajaran ini. Di selasela kegiatan tersebut, peneliti juga melakukan wawancara singkat dengan peserta didik. Peneliti bertanya mengenai tampilan media, penjelasan materi dan kesulitan yang dialami peserta didik ketika menggunakan media. Peneliti juga menanyakan pertanyaanpertanyaan seputar materi yang mereka pelajari untuk melihat apakah peserta didik paham dengan konsep materi yang dipelajarinya. Di akhir pembelajaran, peneliti membagikan angket respon peserta didik dan meminta peserta didik untuk mengisi angket tersebut sesuai dengan pendapat masing-masing. Setelah peserta didik selesai mengisi angket, peneliti melakukan diskusi bersama peserta didik untuk 
memperoleh informasi yang lebih mendalam mengenai media pembelajaran berbasis komputer model tutorial interaktif pada materi relasi dan fungsi kelas VIII.

Peneliti memeriksa catatan yang dibuat oleh peserta didik ketika menggunakan media. Dalam menggunakan media pembelajaran berbasis komputer model tutorial interaktif pada materi pokok relasi dan fungsi kelas VIII, peneliti membuat beberapa soal yang harus dikerjakan oleh peserta didik sesuai dengan uraian materi pembelajaran. Soal latihan tersebut diluar soal-soal latihan yang tersedia pada media pembelajaran. Peneliti juga memeriksa jawaban peserta didik dalam mengerjakan 5 soal latihan. Dari 16 orang peserta didik, 12 orang menjawab semua soal dengan benar, 1 orang menjawab 4 soal dengan benar dan 1 orang menjawab 3 soal dengan benar. Peserta didik paling banyak menjawab salah pada soal materi 4 yaitu bentuk fungsi.

Dari hasil tersebut dapat disimpulkan bahwa pemahaman peserta didik terhadap materi bentuk fungsi sudah baik. Hasil angket respon peserta didik pada uji coba kelompok besar kemudian dianalisis dengan menghitung persentase hasil respon peserta didik pada media pembelajaran berbasis komputer model tutorial interaktif pada materi pokok relasi dan fungsi kelas VIII dengan nilai rata-rata hasil penilaian peserta didik sebesar 0,978 termasuk dalam kategori " sangat baik".

Berdasarkan hasil angket respon peserta didik dan diskusi peneliti dengan peserta didik pada uji coba kelompok besar diperoleh hasil sebagai berikut.

1) Kelebihan Media Pembelajaran

Menurut peserta didik, media pembelajaran berbasis komputer model tutorial interaktif pada materi pokok relasi dan fungsi kelas VIII merupakan media yang sangat bagus. Peserta didik menilai bahwa media pembelajaran berbasis komputer merupakan salah satu media pembelajaran yang inovatif karena mereka baru pertama kali menggunakan media pembelajaran berbasis komputer model tutorial interaktif. Hal ini membuat proses pembelajaran menjadi lebih menyenangkan dan tidak membosankan karena media ini merupakan sesuatu yang baru bagi peserta didik. Cara menggunakan media pembelajaran ini juga sangat mudah karena menggunakan program Microsoft Power Point yang sudah tidak asing bagi peserta didik. Ditambah lagi dengan petunjuk penggunaan yang terdapat pada media. Media pembelajaran ini dilengkapi dengan gambar dan animasi yang menarik sehingga membuat peserta didik lebih bersemangat untuk belajar.

Dengan adanya animasi-animasi dalam penjelasan materi juga membuat peserta didik mudah memahami penjelasan materi tersebut. Peserta didik mengatakan bahwa media pembelajaran berbasis komputer model tutorial interaktif pada materi pokok relasi dan fungsi kelas VIII sudah sangat baik. Peserta didik juga mengharapkan agar media pembelajaran berbasis komputer model tutorial interaktif pada materi pokok relasi dan fungsi kelas VIII dapat segera digunakan dalam pembelajaran di sekolah.

2) Kekurangan Media Pembelajaran

Dari hasil uji coba kelompok besar, media pembelajaran berbasis komputer model tutorial interaktif pada materi pokok relasi dan fungsi dinilai sangat baik. Kekurangan yang terdapat pada media pembelajaran ini hanya kesalahan penulisan. Peserta didik menyarankan untuk menambah gambar dalam media pembelajaran karena ada gambar yang sering muncul. Sebaiknya dilakukan penambahan gambar, agar gambar dalam media pembelajaran lebih beragam sehingga tidak membuat peserta didik bosan. Salah satu peserta didik juga menyarankan sebaiknya ditambahkan suara atau audio agar media pembelajaran lebih menarik. Namun, diperlukan perangkat tambahan berupa headset agar audio dapat didengar dengan jelas dan tidak menimbulkan suara yang mengganggu orang lain jika digunakan di kelas. Berdasarkan pertimbanagn tersebut, peneliti tidak menambahkan audio dalam media pembelajaran berbasis komputer model tutorial interaktif pada materi pokok relasi dan fungsi kelas VIII.

\section{Revisi Produk}

Berdasarkan hasil dari uji coba kelompok besar, peneliti melakukan revisi terhadap media pembelajaran berbasis komputer model tutorial interaktif pada materi pokok relasi dan fungsi kelas VIII. Secara keseluruhan tidak terlalu banyak perbaikan yang dilakukan peneliti karena hasil uji coba kelompok besar sangat baik. Revisi yang dilakukan peneliti dapat dilihat pada Tabel 7. Kemudian, peneliti mengecek seluruh komponen media 
pembelajaran hingga pertemuan terakhir. Setelah peneliti selesai merevisi media, media pembelajaran berbasis komputer model tutorial interaktif pada materi pokok relasi dan fungsi kelas VIII kemudian dikemas dalam Compact Disk (CD).

Tabel 7. Revisi Media Pembelajaran setelah Uji Coba Kelompok Besar

\begin{tabular}{|c|c|c|c|}
\hline No & Media & $\begin{array}{c}\text { Penilaian } \\
\text { dan Saran } \\
\text { Peserta } \\
\text { Didik }\end{array}$ & $\begin{array}{l}\text { Hasil } \\
\text { Revisi }\end{array}$ \\
\hline 1. & $\begin{array}{l}\text { Beberapa } \\
\text { gambar } \\
\text { pada media } \\
\text { dipakai } \\
\text { berulang }\end{array}$ & $\begin{array}{l}\text { Ditambah } \\
\text { kan } \\
\text { gambar } \\
\text { agar } \\
\text { gambar } \\
\text { yang } \\
\text { terdapat } \\
\text { pada } \\
\text { media } \\
\text { lebih } \\
\text { beragam }\end{array}$ & $\begin{array}{l}\text { Menambah } \\
\text { kan gambar } \\
\text { dengan } \\
\text { mengganti } \\
\text { gambar } \\
\text { yang terlalu } \\
\text { sering } \\
\text { dipakai }\end{array}$ \\
\hline .2 & $\begin{array}{l}\text { Terdapat } \\
\text { kesalahan } \\
\text { pengetikan }\end{array}$ & $\begin{array}{l}\text { Perbaiki } \\
\text { pengeti } \\
\text { kan } \\
\text { pada } \\
\text { materi } \\
\text { pembela } \\
\text { jaran. }\end{array}$ & $\begin{array}{l}\text { Pengetikan } \\
\text { diperbaiki } \\
\text { pada materi } \\
\text { pembelajar } \\
\text { an }\end{array}$ \\
\hline
\end{tabular}

Peserta didik mengatakan bahwa tampilan media pembelajaran sangat menarik dan bahasa yang digunakan mudah dimengerti. Dengan adanya animasi-animasi dalam media pembelajaran membuat peserta didik mudah memahami materi pembelajaran. Hal ini dikarenakan peserta didik lebih mudah memahami materi dengan melihat ilustrasi yang terdapat pada media pembelajaran yang disertai dengan penjelasannya daripada penjelasan secara verbal yang sering dilakukan oleh guru. Hal ini sejalan dengan fungsi media yang dikemukakan oleh Sadiman (2011) bahwa media dapat memperjelas penyajian pesan agar tidak terlalu verbalistis (lisan belaka). Sebagaimana juga telah diungkapkan oleh Edgar Dale (Sari, 2019) pada kerucut pengalaman, bahwa ketika peserta didik hanya mendengarkan dalam proses pembelajaran maka yang dapat diingat hanya $20 \%$.

Peserta didik mudah memahami materi yang disajikan dalam media pembelajaran karena informasi yang diterima oleh peserta didik tidak abstrak. Penggunaan media pembelajaran memberikan dampak terhadap pemrolehan dan pertumbuhan pengetahuan, keterampilan, dan sikap peserta didik. Hal ini diperjelas oleh Arsyad (2011) yang mengatakan bahwa pemerolehan pengetahuan dan keterampilan, perubahan-perubahan sikap dan perilaku dapat terjadi karena interaksi antara pengalaman baru dengan pengalaman yang pernah dialami sebelumnya.

Materi dan latihan soal yang terdapat pada media dinilai sangat baik untuk melihat pemahaman peserta didik terhadap materi yang telah dipelajarinya. Peserta didik menilai bahwa mereka dapat belajar sesuai dengan keinginan mereka sendiri di mana mereka dapat mengulang penjelasan materi jika mereka belum mengerti ataupun dapat melanjutkan penjelasan materi jika sudah mengerti. Ini merupakan salah satu kelebihan model tutorial interaktif yang telah dikemukakan oleh Sanjaya (2012).

Dari uraian hasil validasi dan hasil angket respon peserta didik terhadap media pembelajaran berbasis komputer model tutorial interaktif pada materi pokok relasi dan fungsi kelas VIII, dapat disimpulkan bahwa media pembelajaran berbasis komputer model tutorial interaktif pada materi pokok relasi dan fungsi kelas VIII sudah valid dan memenuhi syarat praktikalitas untuk digunakan peserta didik kelas VIII.

\section{SIMPULAN}

Bahan ajar/media pembelajaran matematika berbasis komputer model tutorial interaktif pada materi pokok relasi dan fungsi kelas VIII telah diteliti dan disimpulkan dengan hasil sebagai berikut.

1. Hasil validasi dari para validator menunjukkan bahwa bahan ajar matematika berbasis komputer model tutorial interaktif pada materi pokok relasi dan fungsi kelas VIII telah valid. Hal ini berarti bahan ajar tersebut telah sesuai dengan apa yang diharapkan.

2. Hasil uji coba yang dilakukan di kelas VII SMP IT Raudhatur Rahmah Pekanbaru menunjukkan bahan ajar berbasis komputer model tutorial interaktif materi pokok relasi dan fungsi kelas VIII sudah praktis. 
3. Berdasarkan deskripsi dari analisis data wawancara dan lembar tanggapan peserta didik dapat disimpulkan bahwa bahan ajar efektif dalam memunculkan aktivitas belajar peserta didik.

\section{DAFTAR PUSTAKA}

Arsyad, A. (2011). Media Pembelajaran. Jakarta: PT. Raja Grafindo Persada.

Bahri, S. (2010). Strategi Belajar Mengajar. Jakarta: PT Rineka Cipta.

Sadiman, S. A., dkk. (2011). Media Pendidikan. Jakarta: PT. Raja Grafindo Persada.
Sanjaya, W. (2012). Media Komunikasi Pembelajaran. Jakarta: Kencana Prenada Media

Sari, P. (2019). Analisis Terhadap Kerucut Pengalaman Edgar Dale dan Keragaman Gaya Belajar Untuk Memilih Media yang Tepat Dalam Pembelajaran. Jurnal Manajemen Pendidikan, 1(1), 58 - 78

Sugiyono. (2011). Metode Penelitian Kuantitatif, Kualitatif dan R\&D. Bandung: Alfabeta. 